\title{
Cadmium and Zinc Uptake Characteristics of Corn Plant in Arable Soil Contaminated by Smelting Factory Source
}

\author{
Chang On Hong ${ }^{1)}$, Jessie Gutierrez"), Ju Hwan Oh"1), \\ Yong Bok Lee ${ }^{2)}$, Chan $\mathrm{Yu}^{3,4)}$, and Pil Joo Kim ${ }^{1,4) *}$ \\ ${ }^{1)}$ Division of Applied Life Science (BK21), Gyeongsang National University, Jinju, 660-701, South Korea \\ ${ }^{2)}$ National Institute of Agricultural Science \& Technology, RDA, Suwon, 441-707, South Korea \\ ${ }^{3)}$ Department of Agricultural Engineering, Gyeongsang National University, Jinju, 660-701, South Korea \\ ${ }^{4)}$ Institute of Agriculture and Life Science, Gyeongsang National University, Jinju, 660-701, South Korea
}

(Received September 4, 2007, Accepted September 23, 2007)

\begin{abstract}
The cadmium (Cd) and zinc $(\mathrm{Zn})$ contamination of soils and cultivated crop plants by zinc smelting activities was studied. In the study area of the vicinity of $\triangle \Delta$ zinc smelting factory in Korea, soils and com plants were sampled at com harvesting stage and analyzed $\mathrm{Cd}$ and $\mathrm{Zn}$ concentration, as well as $\mathrm{Cd}$ and $\mathrm{Zn}$ fraction and chemical properties in soils. At $600 \mathrm{~m}$ radius of studied area, $\mathrm{Cd}$ and $\mathrm{Zn}$ were highly accumulated in the surface soils $(0-20 \mathrm{~cm})$ showed greater than the Korean waming criteria $(\mathrm{Cd} 1.5$, Zn $300 \mathrm{mg} \mathrm{kg}^{-1}$ ) with comesponding values 1.7 and $407 \mathrm{mg} \mathrm{kg}^{-1}$, respectively. The leaf part gave higher Cd concentration with the corresponding value of $9.5 \mathrm{mg} \mathrm{kg}^{-1}$ as compared to the stem and grains parts (1.6 and 0.18 $\mathrm{mg} \mathrm{kg}$ ), respectively. Higher $\mathrm{Zn}$ concentration was also obtained from the leaf part of the com plant which gave the value of $1,733 \mathrm{mg} \mathrm{kg}$. The stem and grain part gave corresponding values of 547 and $61 \mathrm{mg}$ $\mathrm{kg}^{-1}$. The order of the mean $\mathrm{Cd}$ concentration in fractions is $\mathrm{F3}$ (oxidizable fraction) $>\mathrm{F} 2$ (reducible fraction) $>$ F4 (residual fraction) > F1 (exchangeable + acidic fraction). A highly positive comelation is observed between $\mathrm{F} 2$ and concentration of $\mathrm{Cd}$ and $\mathrm{Zn}$ in both plant parts, leaf and grain. Highly positive comelations are shown in the $\mathrm{pH}$, exchangeable $\mathrm{Ca}$ and $\mathrm{Mg}$, and $\mathrm{CEC}$ when conelated with $\mathrm{Cd}$ and $\mathrm{Zn}$ bound to $\mathrm{F4}$ fractions. To reduce $\mathrm{Cd}$ and $\mathrm{Zn}$ uptake by com plant in an arable land heavily contaminated with $\mathrm{Cd}$ and $\mathrm{Zn}$ as affected by smelting factory, an efficient and effective soil management to increase soil pH and CEC is thus recommended.
\end{abstract}

Key Words: Zinc smelting factory, cadmium, zinc, fraction

\section{INTRODUCTION}

$\triangle \triangle$ zinc factory $\left(129^{\circ} 03^{\prime} 48^{\prime \prime} \mathrm{N}\right.$ and $\left.37^{\circ} 02^{\prime} \mathrm{E}\right)$ located in the southeastern part of the Korean peninsula is the third largest zinc smelting factory in the world. This factory was founded in 1970 s and now produces 450,000 tons of sulfuric acid $\left(\mathrm{H}_{2} \mathrm{SO}_{4}\right), 280,000$ tons of zinc, 1,700 tons of cupric sulfate and 900 tons of cadmium per year. However, there were issues previously reported about its ill-health effects to the heavy metal exposed workers, its living communities and in the

"Corresponding author:

Tel: +82-55-751-5466 Fax: +82-55-757-0178

E-mail: pjkim@gsnu.ac.kr environment. Crop plants growing on heavy metal contaminated medium can accumulate high concentrations of trace elements to cause serious health risk to consumers ${ }^{1)}$. Around 20 hectares of cultivated lands nearby the factory are planted mainly into corn, then some minor land area into radish, red pepper, and sesame plant. As grains of corn plant are consumed by human beings while fresh corn stover is utilized as feeding materials for ruminants, this was used as the sole test crop.

Cadmium is a toxic element and $\mathrm{Zn}$ in high concentrations, and numerous investigations showed that the pronounced amount of $\mathrm{Cd}$ and $\mathrm{Zn}$ were often found in arable soil adjacent to a non-ferrous metal 
production bases ${ }^{2-4)}$. The processing and subsequent release of zinc to the environment is normally accompanied by cadmium environmental pollution because of zinc ores (ZnS) generally containing $0.1-5 \%$ and sometimes even higher cadmium ${ }^{5}$. Cadmium, unessential to plants, and zinc, essential to plants, are elements having similar geochemical and environmental properties. These two metals are exchangeable and somewhat mobile elements in soils ${ }^{6}$. Heavy metal uptake by roots depends on both soil and crop plant factors (e.g. source and chemical form of elements in soil, $\mathrm{pH}, \mathrm{CEC}$, organic material, plant species, plant age, etc). Heavy metals present in various forms in soil. Different forms of heavy metals have different mobility and phytovavailability ${ }^{7}$. Knowledge of the heavy metal speciation in soil amended with sewage sludge is important for the understanding of the bioavailability and mobility of heavy metals in soils. Generally, the plant uptake of heavy metals is correlated to extractable forms of the metals rather than to the total metal contents in the soil ${ }^{8}$. The distribution of heavy metals among the water soluble, exchangeable + acidic, reducible, organic and residual fractions using sequential extraction analysis could assess the potential phytoavailability of heavy metals in soil.

Accumulation of $\mathrm{Cd}$ and $\mathrm{Zn}$ in plant parts in solution culture or in pot experiment had been reported ${ }^{3,9-13)}$. However to our knowledge, there is little information about the fate and behaviors of the metals in crop tissues in fields. Therefore, the present investigation was undertaken to examine the metal distribution of $\mathrm{Cd}$ and $\mathrm{Zn}$ in the corn plant and their phytoavailability. The objectives of this study are mainly to; (1) investigate the degree of trace element contamination of soils located nearby the smelting factory; (2) show the metal distribution of $\mathrm{Cd}$ and $\mathrm{Zn}$ in different parts of the corn plant; (3) assess phytoavailability of $\mathrm{Cd}$ and $\mathrm{Zn}$ in soil through sequential fractionation; and (4) determine the relationship between the soil properties and phytoavailability of $\mathrm{Cd}$ and $\mathrm{Zn}$.

\section{Materials and methods}

\subsection{Soils}

Sampling of soils was carried out on 7 August, 2006 to examine concentration of heavy metals. The sampling locations and topography of the study area are shown in Fig. 1. Soils $(0-20 \mathrm{~cm}, 40-60 \mathrm{~cm}$, and 60 $-80 \mathrm{~cm}$ in depth) were sampled by hand auger $(2.5 \mathrm{~cm}$ in diameter) in the arable lands nearby the smelting factory with an estimated land area at 20 hectares. Twenty samples were randomly collected from these sites. The concentration of $\mathrm{Cd}$ and $\mathrm{Zn}$ were analyzed following the standard method which was established by the Korean Soil Environmental Conservation $\mathrm{Act}^{14)}$. For analysis of $\mathrm{Cd}$ concentrations sieved soil samples ( $<2 \mathrm{~mm}$ ) were extracted by $0.1 \mathrm{~N} \mathrm{HCl}$ solution, for $\mathrm{Zn}$ (finely milled soil samples, $<180 \mu \mathrm{m}$ ) were digested in 3:1 concentrated $\mathrm{HCl}$ and $\mathrm{HNO}_{3}$ (aqua regia). The extracted solutions were analyzed for $\mathrm{Cd}$ and $\mathrm{Zn}$ concentrations through AAS (atomic adsorption spectrophotometer GBC Model AVANTA PM, Melbourne Australia). The sieved soils $(<2 \mathrm{~mm})$ were analyzed for chemical properties as follows : $\mathrm{pH}\left(1: 5\right.$ with $\left.\mathrm{H}_{2} \mathrm{O}\right)$, organic matter content ${ }^{15}$. The available $\mathrm{P}$ content was determined using the Lancaster method (5 $\mathrm{g}$ soil were

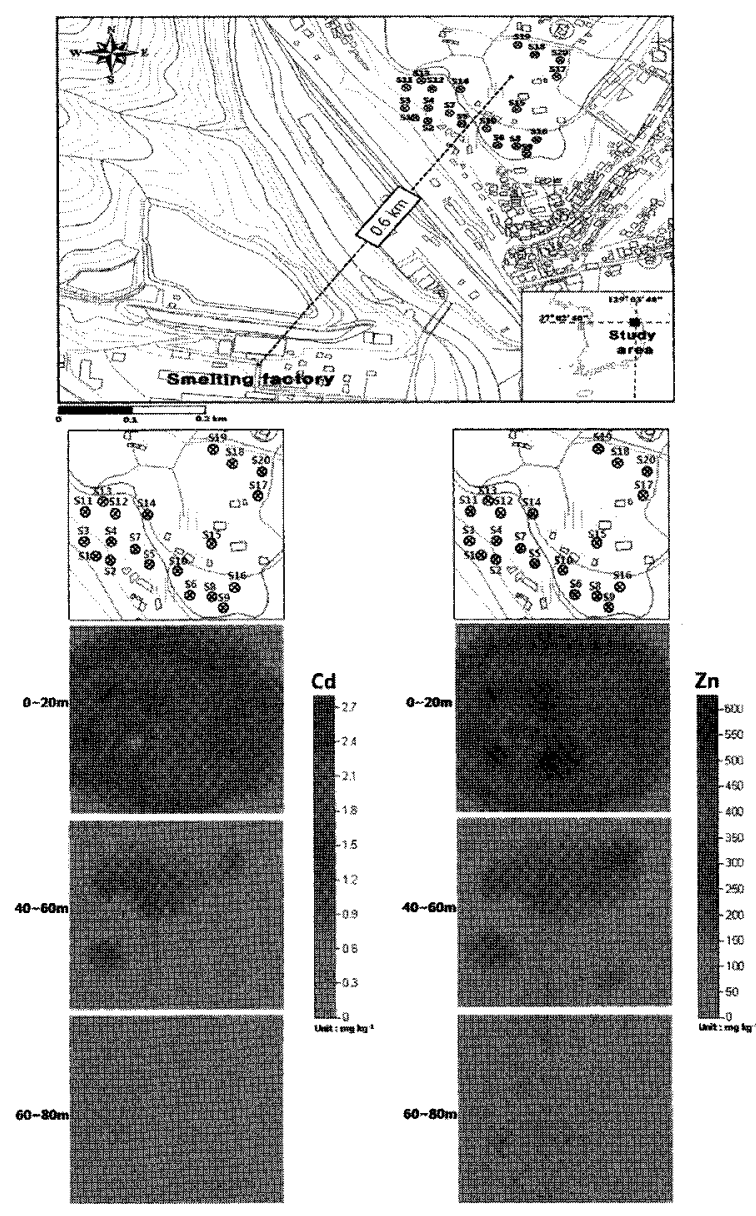

Fig. 1. Distribution of $\mathrm{Cd}$ and $\mathrm{Zn}$ concentration in soil sampled by depth in the vicinity of the $\triangle \triangle$ smelting factory. 
extracted with $20 \mathrm{ml}$ of $0.33 \mathrm{M} \mathrm{CH}_{3} \mathrm{CHOOH}, 0.15 \mathrm{M}$ lactic acid, $0.03 \mathrm{M} \mathrm{NH}_{4} \mathrm{~F}, 0.05 \mathrm{M}\left(\mathrm{NH}_{4}\right)_{2} \mathrm{SO}_{4}$ and 0.2 $\mathrm{M} \mathrm{NaOH}$ at $\mathrm{pH} 4.25)^{16)}$. Exchangeable $\mathrm{Ca}^{2+}, \mathrm{Mg}^{2+}$, and $\mathrm{K}^{+}$were extracted with $1 \mathrm{M} \mathrm{NH}_{4} \mathrm{OAc}(\mathrm{pH} 7.0)$ at a soil : solution ratio of $1: 5$ for $1 \mathrm{~h}$. The solutions were analyzed by ICP-OES (inductively coupled plasma optical emission spectrophotometer Perkin Elmer Model OPTIMA 4300 DV, Shelton USA). Cation exchange capacity of soil was measured using $0.1 \mathrm{M} \mathrm{NaCl}$ following the ion retention method of Schofield ${ }^{17)}$. Cadmium and $\mathrm{Zn}$ was fractionated by a modified sequential extraction procedure of BCR (the community Bureau of Reference now the European Union "Measurement and Testing Program") to water soluble, exchangeable + acidic, reducible, oxidizable, and residual fraction ${ }^{18)}$. Extractions were conducted in $50 \mathrm{ml}$ polypropylene centrifuge tubes. The supernatant was centrifuged at $6000 \mathrm{rpm}$ for $15 \mathrm{~min}$, and filtered between each successive extraction.

\subsection{Crop plants}

The vegetation of arable land nearby smelting factory consists of various crop plant mainly planted into corn, then a small portion of radish, red pepper, and sesame plant. The corn plant was selected as the main test crop as it is the major crop cultivated in the affected area and was divided into three main parts, namely, stem, leaf and grain plant tissue samples. The samples were thoroughly washed in deionized water, oven-dried at $70^{\circ} \mathrm{C}$ for $72 \mathrm{~h}$, ground, and digested using a solution of $\mathrm{HNO}_{3}: \mathrm{H}_{2} \mathrm{SO}_{4}: \mathrm{HClO}_{4}(10: 1$ $: 4$ volume/volume) for $\mathrm{Cd}$ and $\mathrm{Zn}$. Cadmium and $\mathrm{Zn}$ were determined by using AAS.

\section{Results and Discussions}

\subsection{Contamination of $\mathrm{Cd}$ and $\mathrm{Zn}$ in arable soil}

$\mathrm{Cd}$ and $\mathrm{Zn}$ were highly accumulated more than the Korean warning criteria ( $\mathrm{Cd} 1.5, \mathrm{Zn} 300 \mathrm{mg} \mathrm{kg}^{-1}$ ) with mean values 1.7 and $407 \mathrm{mg} \mathrm{kg}^{-1}$, respectively, at the surface soils $(0-20 \mathrm{~cm})$. Higher concentration of $\mathrm{Cd}$ and $\mathrm{Zn}$ were found at the sample surface soil collected at $0-20 \mathrm{~cm}$ than in the other layers of its soil profile (Fig. 1). In addition for $\mathrm{Cd}$, concentration decreased significantly at the increasing soil depth at $40-60 \mathrm{~cm}$ and $60-80 \mathrm{~cm}$. The same distribution can be observed too in $\mathrm{Zn}$ which also decreased significantly at increasing soil depths. A higher $\mathrm{Cd}$ and $\mathrm{Zn}$ concentration at the surface soil than in the subsoil horizons may mean that the heavy metal sources doesn't come from the parent materials but from its external environment.

\subsection{Distribution of $\mathrm{Cd}$ and $\mathrm{Zn}$ in corn plant}

Table 1 shows the narrow variation in the $\mathrm{Cd}$ and $\mathrm{Zn}$ metal distribution in the stem, leaf and grain of the corn plant from all sampling sites. The leaf part gave higher $\mathrm{Cd}$ concentration with the corresponding value of $9.5 \mathrm{mg} \mathrm{kg}^{-1}$ as compared to the stem and grains parts ( 1.6 and $0.18 \mathrm{mg} \mathrm{kg}^{-1}$ ), respectively. Higher $\mathrm{Zn}$ concentration was also obtained from the leaf part of the corn plant which gave the value of $1,733 \mathrm{mg}$ $\mathrm{kg}^{-1}$. The stem and grain part gave corresponding values of 547 and $61 \mathrm{mg} \mathrm{kg}^{-1}$. Concentrations of $\mathrm{Cd}$ and $\mathrm{Zn}$ concerned in plant parts showed that the highest concentrations in the corn plant occurred in leaf, the lowest in grain. Corn leaf contained 26-105 times the content found in grains for $\mathrm{Cd}$, and $17-46$ times for Zn. Corn stem contained 3-24 times the level discovered in grains for $\mathrm{Cd}$, and $2-14$ times for $\mathrm{Zn}$ (Table 1). These results similar with the previous pot reports of Dudka et al. ${ }^{3)}$, who found that the concentrations of $\mathrm{Cd}$ and $\mathrm{Zn}$ in spring wheat plant were higher in straw than in grain by factors $1.5-2$ and 3-7 for $\mathrm{Cd}$ and $\mathrm{Zn}$, respectively and the field experiment of Granato et al. ${ }^{19)}$ who reported that the leaf part gave higher $\mathrm{Cd}$ concentration with the corresponding value of $10 \mathrm{mg} \mathrm{kg}^{-1}$ as compared to the grains

Table. 1. Cd and $\mathrm{Zn}$ concentration in corn plant cultivated in target soil sampling site

\begin{tabular}{cccccc}
\hline \multirow{2}{*}{ Corn plant } & \multicolumn{2}{c}{${\mathrm{Cd}\left(\mathrm{mg} \mathrm{kg}^{-1}\right)}$} & & \multicolumn{2}{c}{$\mathrm{Zn}\left(\mathrm{mg} \mathrm{kg}^{-1}\right)$} \\
\cline { 2 - 3 } & $\mathrm{AM} \pm \mathrm{SD}^{1)}$ & Range & & $\mathrm{AM} \pm \mathrm{SD}$ & Range \\
\hline Stem & $1.6 \pm 0.5$ & $0.5-2.6$ & & $547 \pm 206$ & $105-943$ \\
Leaf & $9.5 \pm 1.7$ & $7.0-12.3$ & & $1,733 \pm 498$ & $1,043-2,803$ \\
Grain & $0.18 \pm 0.08$ & $0.1-0.4$ & & $61 \pm 22$ & $34-123$ \\
\hline
\end{tabular}

${ }^{1)} \mathrm{AM} \pm \mathrm{SD}$ means arithmetic mean \pm standard deviation 
parts $\left(0.2 \mathrm{mg} \mathrm{kg}^{-1}\right)$. Hong et $\mathrm{al}^{20)}$ reported that $\mathrm{Cd}$ was more concentrated (4.1 - 5.9 times) in shoots than in roots under field experiment. Cadmium and $\mathrm{Zn}$ concentrations in the stems and leaves were higher compared to the grains. $80 \%$ ( 16 out of 20 ) and $85 \%$ (17 out of 20) of the grain samples yielded higher concentration of $\mathrm{Cd}$ and $\mathrm{Zn}$ than the maximum safe intake level for $\mathrm{Cd}\left(0.1 \mathrm{mg} \mathrm{kg}^{-1}\right)$ and $\mathrm{Zn}\left(40 \mathrm{mg} \mathrm{kg}^{-1}\right)$ established by FAO/WHO (Food and Agriculture Organization/World Health Organization) and Bowen ${ }^{21)}$, respectively. In Korea, only maximum permit limits of $\mathrm{Cd}$ and $\mathrm{Pb}$ in rice plant are established but still none for other crops. Moreover as grains are consumed by human beings, leaf and stems are consumed by animals as feeding stuff. Leaf parts of corn plant sampled in arable land near by smelting factory contained high amount of $\mathrm{Zn}$ (mean $1,733 \mathrm{mg} \mathrm{kg}^{-1}$ ). High concentration of $\mathrm{Cd}$ and $\mathrm{Zn}$ in leaf and stem parts can cause serious health problem to animals. Just like, the grazing animal can ingest the metals either by consuming herbage that is internally or externally contaminated ${ }^{22}$. Of particular concern is $\mathrm{Cd}$, because of the relatively low threshold toxicity on the part of the animal to the presence of relatively low concentration of this element in the body.

\subsection{Fractionation of $\mathrm{Cd}$ and $\mathrm{Zn}$ in soil}

In Table 2, the concentrations of $\mathrm{Cd}$ and $\mathrm{Zn}$ fractions in the soil samples are shown. The order of the mean $\mathrm{Cd}$ concentration in fractions is $\mathrm{F} 3$ (oxidizable fraction) $>$ F2 (reducible fraction) $>$ F4 (residual fraction) $>$ F1 (exchangeable + acidic fraction). Highest mean concentration in $\mathrm{Cd}$ was obtained from $\mathrm{F} 3$ with a value of $1.0 \mathrm{mg} \mathrm{kg}^{-1}$ ( $38.5 \%$ of total Cd concentration). Other fractions gave corresponding values of 0.8 (30.7 $\%), 0.5(19.2 \%)$ and $0.2(7.7 \%) \mathrm{mg} \mathrm{kg}^{-1}$ for F2, F4 and $\mathrm{F} 1$, respectively. In zinc concentrations, $\mathrm{F} 3$ also gave highest value of $191 \mathrm{mg} \mathrm{kg}^{-1}$ followed by values of $86(21.1 \%), 81(19.9 \%)$ and $50(12.3 \%) \mathrm{mg} \mathrm{kg}^{-1}$ for $\mathrm{F} 4$, $\mathrm{F} 2$, and F1, respectively showing the trend F3 $>\mathrm{F} 4$ $>\mathrm{F} 2>\mathrm{F} 1$.

Table 3 shows the correlation of concentrations between the soil $\mathrm{Cd}, \mathrm{Zn}$ fractions and the plant. $\mathrm{Cd}$ concentration in F1 showed a positive correlation with

Table 2. Concentration of $\mathrm{Cd}$ and $\mathrm{Zn}$ fractions in soil samples collected in the targeted sites

\begin{tabular}{|c|c|c|c|c|}
\hline \multirow{2}{*}{ Fraction $^{1)}$} & \multicolumn{2}{|c|}{$\mathrm{Cd}\left(\mathrm{mg} \mathrm{kg}^{-1}\right)$} & \multicolumn{2}{|c|}{$\mathrm{Zn}\left(\mathrm{mg} \mathrm{kg}^{-1}\right)$} \\
\hline & $\mathrm{AM} \pm \mathrm{SD}^{2)}$ & Range & $\mathrm{AM} \pm \mathrm{SD}$ & Range \\
\hline F1 & $0.2 \pm 0.1(7.7 \%)^{3)}$ & $0.1-0.5$ & $50 \pm 25(12.3 \%)$ & $13-130$ \\
\hline F2 & $0.8 \pm 0.4(30.7 \%)$ & $0.3-1.9$ & $81 \pm 41(19.9 \%)$ & $21-217$ \\
\hline F3 & $1.0 \pm 0.4(38.5 \%)$ & $0.3-1.9$ & $191 \pm 68(46.9 \%)$ & $60-302$ \\
\hline $\mathrm{F} 4$ & $0.5 \pm 0.5(19.2 \%)$ & $0.01-2.3$ & $86 \pm 65(21.1 \%)$ & $4-280$ \\
\hline F5 & $2.6 \pm 0.9(100 \%)$ & $0.8-4.1$ & $407 \pm 142(100 \%)$ & $105-641$ \\
\hline
\end{tabular}

${ }^{1)}$ Fraction : F1 : Exchangeable + acidic fraction, F2 : Reducible fraction, F3 : Oxidizable fraction, F4 : Residual fraction, F5 : Total concentration

${ }^{2)} \mathrm{AM} \pm \mathrm{SD}$ means arithmetic mean \pm standard deviation

() ) means the proportion of each fraction (\%) to total concentration

Table 3. Correlation between plant heavy metal concentration and soil heavy metal concentration

\begin{tabular}{|c|c|c|c|c|c|c|}
\hline \multirow{2}{*}{ Fraction $^{1)}$} & \multicolumn{3}{|c|}{$\mathrm{Cd}\left(\mathrm{mg} \mathrm{kg}{ }^{-1}\right)$} & \multicolumn{3}{|c|}{$\mathrm{Zn}\left(\mathrm{mg} \mathrm{kg}{ }^{-1}\right)$} \\
\hline & Stem & Leaf & Grain & Stem & Leaf & Grain \\
\hline $\mathrm{F} 1$ & 0.278 & $0.506^{*}$ & $0.502^{*}$ & 0.214 & $0.610^{* *}$ & $0.698^{* * *}$ \\
\hline $\mathrm{F} 2$ & 0.196 & $0.578^{* *}$ & $0.557^{* *}$ & 0.277 & $0.701^{* * *}$ & $0.754^{* * *}$ \\
\hline F3 & -0.087 & 0.238 & 0.315 & -0.334 & 0.297 & 0.304 \\
\hline F4 & -0.237 & -0.176 & -0.241 & $-0.535^{*}$ & -0.338 & $-0.445^{*}$ \\
\hline F5 & -0.057 & 0.282 & 0.251 & -0.317 & 0.261 & 0.222 \\
\hline
\end{tabular}

${ }^{1)}$ Fraction : F1 : Exchangeable + acidic fraction, F2 : Reducible fraction, F3 : Oxidizable fraction, F4 : Residual fraction, F5 : Total concentration

2)***, and *** denote significance at 95,99 , and $99.9 \%$ level, respectively 
the $\mathrm{Cd}$ leaf and grain contents with corresponding values of $0.506^{*}$ and $0.502^{*}$, respectively. Between F2 and $\mathrm{Cd}$ in leaf and grain, both parts show high correlation $\left(0.578^{* *}\right.$ and $\left.0.557^{* *}\right)$. F3 showed a low positive correlation with the $\mathrm{Cd}$ leaf and grain contents with corresponding values of 0.238 and 0.315 , respectively. High positive correlation is observed between F1and $\mathrm{Zn}$ leaf $\left(0.610^{* *}\right)$ and grain $\left(0.698^{* * *}\right)$. A high positive correlation too is observed between F2 in both plant parts, leaf and grain with values $0.701^{* * *}$ and $0.754^{* * *}$, respectively. The F3 showed a low positive correlation in leaf and grain (0.297 and 0.304). However, F4 showed neagtive correlation with the $\mathrm{Zn}$ leaf and grain contents. Even though, highest mean concentrations in $\mathrm{Cd}$ and $\mathrm{Zn}$ in soil were obtained from F3, between $\mathrm{F} 2$ and $\mathrm{Cd}$ and $\mathrm{Zn}$ in leaf and grain, both parts show the highest correlation which means that F1 and F2 among the $\mathrm{Cd}$ and $\mathrm{Zn}$ fractions are easily absorbed by corn plant, but scarcely in F4. Metals confined in the exchangeable and bound to carbonates are likely to affect sorption-desorption process in soil. And metals bound to iron and manganese oxides are thermodynamically unstable under anoxic conditions (i.e., low Eh) in soils ${ }^{23)}$. Metal confined in the residual fractions are usually not expected to be released over short period of time under the conditions usually encountered in nature ${ }^{7,23)}$.

\subsection{Relationship between the soil properties and phytoavailability of $\mathrm{Cd}$ and $\mathrm{Zn}$}

Uptake of heavy metals by plants are not only influenced by their concentrations in soil, but also by their chemical forms and physicochemical properties of soil ${ }^{5,7)}$. Table 4 shows the soil physical and chemical properties. A narrow $\mathrm{pH}$ variation was shown in the results with a corresponding mean value of

Table 4. Chemical properties of soils sampled in the arable land near $\triangle \triangle$ zinc smelting factory.

\begin{tabular}{|c|c|c|c|c|c|c|c|}
\hline \multirow{2}{*}{ Data } & \multirow{2}{*}{$\begin{array}{c}\mathrm{pH} \\
\left(\mathrm{H}_{2} \mathrm{O}, 1: 5\right)\end{array}$} & \multirow{2}{*}{$\begin{array}{c}\mathrm{T}-\mathrm{C} \\
\left(\mathrm{g} \mathrm{kg}^{-1}\right)\end{array}$} & \multirow{2}{*}{$\begin{array}{c}\text { Av. P } \\
\left(\mathrm{mg} \mathrm{kg}^{-1}\right)\end{array}$} & \multicolumn{3}{|c|}{ Ex. Cation $\left(\mathrm{cmol}^{+} \mathrm{kg}^{-1}\right)$} & \multirow{2}{*}{$\begin{array}{c}\text { CEC } \\
\left(\mathrm{cmol}^{+} \mathrm{kg}^{-1}\right)\end{array}$} \\
\hline & & & & K & $\mathrm{Ca}$ & $\mathrm{Mg}$ & \\
\hline $\mathrm{AM} \pm \mathrm{SD}$ & $5.3 \pm 0.8$ & $27 \pm 6$ & $345 \pm 135$ & $1.0 \pm 0.4$ & $4.4 \pm 2.8$ & $0.5 \pm 0.5$ & $8.2 \pm 2.8$ \\
\hline Range & $4.4-7.9$ & $19-42$ & $40-573$ & $0.4-2.1$ & $1.3-13$ & $0.03-1.7$ & $5.3-9.2$ \\
\hline
\end{tabular}

Av. P : available phosphorus, T-C : total carbon, Ex. cation: exchangeable cation, CEC : cation exchange capacity

Table 5. Correlation between heavy metal fractions and soil properties

\begin{tabular}{|c|c|c|c|c|c|c|}
\hline \multirow{2}{*}{$\begin{array}{l}\text { Heavy } \\
\text { metal }\end{array}$} & \multirow{2}{*}{$\begin{array}{l}\text { Soil } \\
\text { property }\end{array}$} & \multicolumn{5}{|c|}{ Heavy metal fraction ${ }^{1)}$} \\
\hline & & F1 & $\mathrm{F} 2$ & F3 & $\mathrm{F} 4$ & F5 \\
\hline \multirow{7}{*}{. $\mathrm{Cd}$} & $\mathrm{pH}$ & -0.152 & -0.083 & $0.608^{* *}$ & $0.609 * *$ & $0.550^{*}$ \\
\hline & Av. $\mathrm{P}_{2} \mathrm{O}_{5}$ & -0.165 & -0.302 & 0.122 & $0.484^{*}$ & 0.202 \\
\hline & $\mathrm{OM}$ & 0.358 & $0.480^{*}$ & 0.140 & 0.139 & 0.374 \\
\hline & Ex. K & -0.072 & -0.186 & 0.167 & 0.150 & 0.077 \\
\hline & Ex. Ca & -0.340 & -0.302 & $0.457^{*}$ & $0.737^{* * *}$ & $0.458^{*}$ \\
\hline & Ex. Mg & -0.436 & -0.350 & $0.461^{*}$ & $0.660^{* *}$ & 0.382 \\
\hline & CEC & -0.365 & -0.292 & $0.462^{*}$ & $0.655^{* *}$ & 0.408 \\
\hline \multirow{7}{*}{$\mathrm{Zn}$} & $\mathrm{pH}$ & -0.246 & -0.045 & $0.794^{* * *}$ & $0.777^{* * *}$ & $0.672^{* *}$ \\
\hline & Av. $\mathrm{PsO}_{5}$ & -0.221 & -0.165 & 0.396 & 0.434 & 0.298 \\
\hline & OM & 0.350 & $0.470^{*}$ & 0.163 & 0.076 & 0.310 \\
\hline & Ex. K & -0.068 & -0.109 & 0.274 & 0.267 & 0.208 \\
\hline & Ex. Ca & -0.393 & -0.253 & $0.700^{* * *}$ & $0.825^{* * *}$ & $0.563^{* *}$ \\
\hline & Ex. $\mathrm{Mg}$ & $-0.455^{*}$ & -0.306 & $0.679^{* * *}$ & $0.750^{* * *}$ & $0.493^{*}$ \\
\hline & CEC & -0.347 & -0.213 & $0.629^{* * *}$ & $0.766^{* * *}$ & $0.523^{*}$ \\
\hline
\end{tabular}

${ }^{1)}$ Heavy metal fraction : F1 : Exchangeable + acidic fraction, F2 : Reducible fraction, F3 : Oxidizable fraction, F4 : Residual fraction, F5 : Total concentration

2)*,**, and $* * *$ denote significance at 95,99 , and $99.9 \%$ level, respectively 
5.3. Mean total carbon content is $27 \mathrm{mg} \mathrm{kg}^{-1}$. Average available phosphorus corresponds to a value of 345 $\mathrm{mg} \mathrm{kg}{ }^{-1}$. Mean values for exchangeable cations such as $\mathrm{K}, \mathrm{Ca}$ and $\mathrm{Mg}$ are $1.0,4.4$ and $0.5 \mathrm{cmol}^{+} / \mathrm{kg}$. The average $\mathrm{CEC}$ is $8.2 \mathrm{cmol}^{+} / \mathrm{kg}$.

Table 5 shows the correlation between the heavy metal fractions and soil properties. A highly positive correlation is shown between the soil $\mathrm{pH}$ and $\mathrm{Cd}$ in $\mathrm{F} 3$ and F4 with values $0.608^{* *}$ and $0.609^{* *}$, respectively. Cadmium concentrations in F4 correlated with exchangeable $\mathrm{Ca}$ and $\mathrm{Mg}$ gave highly positive results. Cadmium concentrations in $\mathrm{F} 4$ also yield a positive correlation with CEC in the soil. Meanwhile, a similar trend was shown between the soil $\mathrm{pH}$ and $\mathrm{Zn}$ in $\mathrm{F} 3$ and F4 with values $0.794^{* * *}$ and $0.777^{* * *}$, respectively. Cadmium concentrations in F3 and F4 yielded a highly positive correlation when correlated with exchangeable $\mathrm{Ca}$ and $\mathrm{Mg}$. Zinc concentrations in F3 and F4 also yield a positive correlation with CEC in the soil. Cadmium and $\mathrm{Zn}$ in F4 which is scarcely absorbed by corn plant correlated with $\mathrm{pH}$, exchangeable $\mathrm{Ca}$, $\mathrm{Mg}$ and $\mathrm{CEC}$ gave highly positive results. Increases in CEC (negative charge) of soil can cause immobilization of metals ${ }^{24)}$. Calcium addition in the form of lime also causes an inhibition of the uptake and translocation of metal from root to shoot. It is well documented that the availability of $\mathrm{Zn}$ depends on soil $\mathrm{pH}^{5)}$. Soil management to increase $\mathrm{pH}, \mathrm{CEC}$, exchangeable $\mathrm{Ca}$ and $\mathrm{Mg}$ is recommended in reducing $\mathrm{Cd}$ and $\mathrm{Zn}$ uptake by corn plant cultivated in arable land heavily contaminated with $\mathrm{Cd}$ and $\mathrm{Zn}$.

\section{Conclusion}

The present study has examined extent of contamination of arable soils in the vicinity of $\triangle \triangle$ zinc smelting factory and investigated distribution of $\mathrm{Cd}$ and $\mathrm{Zn}$ in different parts of the corn plant and determines the relationship between soil properties and phytoavailability of $\mathrm{Cd}$ and $\mathrm{Zn}$. The arable soils were heavily contaminated with $\mathrm{Cd}$ and $\mathrm{Zn}$. Cadmium and zinc concentrations with the corresponding mean values of 1.7 and $407 \mathrm{mg} \mathrm{kg}^{-1}$ in the soil surface were greater than the warning criteria. The leaf part gave higher $\mathrm{Cd}$ and $\mathrm{Zn}$ concentration compare with stem and grain parts. The order of the mean concentration of $\mathrm{Cd}$ and $\mathrm{Zn}$ fraction in soil is F3 > F2 > F4 > F1. Posi- tive correlation is observed between F1, F2, and F3 and concentration of $\mathrm{Cd}$ and $\mathrm{Zn}$ in both plant parts, leaf and grain. F1, F2, and F3 could be accumulated in the leaf and grain parts of corn plant, but not F4. Highly positive correlations are shown in the $\mathrm{pH}$, CEC, Ex. Ca, and Ex. $\mathrm{Mg}$ when correlated with $\mathrm{Cd}$ and $\mathrm{Zn}$ bound to $\mathrm{F} 4$ fraction. To reduce $\mathrm{Cd}$ and $\mathrm{Zn}$ uptake by corn plant in arable land affected by smelting factory, soil management to increase $\mathrm{pH}, \mathrm{CEC}$, exchangeable $\mathrm{Ca}$ and $\mathrm{Mg}$ is recommended.

\section{Acknowledgements}

This study was supported by Korea Ministry of Environment as "The Eco-technopia 21 project (Project number : 20060082)". Chang Oh Hong, and Ju Hwan Oh were supported by a scholarship from the BK21 Program, the Ministry of Education and Human Resources Development, Korea.

\section{References}

1. Islam E., Yang X., He Z., and Mahmood Q. (2007) Assessing potential dietary toxicity of heavy metals in selected vegetables and food crops. I Zhejiang Univ Sci B 8, 1-13.

2. Pierzynski, G. M. and Schwab, A. P. (1993) Bioavailability of zinc, cadmium and lead in a metal contaminated alluvial soil. J. Environ. Qual. 22, 247-254.

3. Dudka, S., Piotrowska, M., and Chlopecka, A. (1994) Effect of evelvated concentratios of $\mathrm{Cd}$ and $\mathrm{Zn}$ in soil on spring wheat yield and the metal contents of the plants. Water, Air Soil Pollut. 76, 33-341.

4. Dahmain-Muller H., Oort F. V., Gelie B., and Bababane M., 2000.Strategies of heavy metal uptake by the three species growing in a new metal smelter. Environ. Pollut. 109:231-238.

5. Adriano, D. C. (1986) Trace elements in the terrestrial environment. New York : Springer-Verlag, 106-149.

6. McBride, M. B. (1994) Environmental chemistry of soils. Oxford university press.

7. Chlopecka, A. and Adriano, D. C. (1996) Mimicked in-situ stabilization of metals in cropped soil : bioavailability and chemical form of zinc. Environ. Sci. Technol. 30, 3294-3303. 
8. Xian, X. (1988) Effect of chemical forms of cadmium, zinc and lead in polluted soils on their uptake by cabbage plants. Plant and Soil 113, 257-264.

9. Coughtrey, P. J. and Martin, M. H. (1979) Cadmium, lead and zinc interactions and tolerance in two populations of Holcus lanatus L. grown in solution culture. Environ Exp Botany 19, 285-290.

10. Smilde, K. W., Luit, B. V., and Driel, W. V. (1992) The extraction by soil and absorption by plants of applied zinc and cadmium. Plant Soil 143, 233-238.

11. Moraghan, J. T. (1993) Accumulation of cadmium and selected elements in flax seed grown on a calcareous soil. Plant Soil 150, 61-68.

12. Mckenna, I. M., Chaney, R. L., and Williams, F. M. (1993) The effects of cadmium and zinc interactions on the accumulation and tissue distribution of zinc and cadmium in lettuce and spinach. Environ Pollut 79, 113-120.

13. Zhou, Q., Wu, Y., and Xiong, X. (1994) Compound pollution of $\mathrm{Cd}$ and $\mathrm{Zn}$ and its ecological effect on rice plant. Chin J Appl Ecol 5, 428-441.

14. ME (Ministry of Environment, Republic of Korea) (2005) The Korean Soil Environmental Conservation Act, ME. Gwacheon (in Korean).

15. Allison, L. E. (1965) Organic carbon. In Methods of Soil Analysis. Part II, Ed. C. A. Black, p. 1367-1378, Am. Soc. Agron. Inc. Publ., Madison, WI.

16. RDA (Rural Development Administration, Korea) (1988) Methods of Soil Chemical Analysis. National Institute of Agricultural Science and Technology, RDA. Suwon (in Korean).

17. Schofield, R. K. (1949) Effect of pH on electric charges carried by clay particles. J. Soil Sci. 1, 1-8. 18. Ure, A. M., Quevauviller, P. H., Muntau, H., and Griepink, B. (1993) Speciation of heavy metals in soils and sediments. An account of the improvement and harmonization of extraction techniques undertaken under the auspices of the BCR of the Commission of the European Communities. J Environ Anal Chem 51, 135-151.

19. Granato, T. C., Pietz, R. I., Knafl, G. J., Carlson, C. R., Tata, J. P., and Lue-Hing, C. (2004) Trace element concentrations in soil, corn leaves, and grain after cessation of biosolids applications. J. Environ. Qual. 33, 2078-2089.

20. Hong, C. O., Lee, D. K., Chung, D. Y., and Kim, P. J. (2007) Liming effects on cadmium stabilization in upland soil affected by gold mining activity. Environ. Contam. Toxicol. 52, 496-502.

21. Bowen, H. J. M. (1979) Environmental chemistry of the elements. Academic Press, New York.

22. Aitken, M. N. (1997) Short term leaf surface adhesion of heavy metals following application of sewage sludge to grassland. Grass and Forage Science 52, 73-85.

23. Tessier, A., Campbell, P. G. C., and Bisson, M. (1979) Sequential extraction procedure for the speciation of particulate trace metals. Analytical Chemistry. 51, 844-851.

24. Bolan, N. S., Naidu, R., Khan, M. A. R., Tillman, R. W., and Syers, J. K. (1999) The effects of anion sorption on sorption and leaching of cadmium. Aust J Soil Res 37, 445-460. 